\title{
CHATK CHAKIÑAN
}

Número 12 / DICIEMBRE, 2020 (95-117)

\section{Elsa Hernández-Chérrez}

eda.hernandez@uta.edu.ec

Universidad Técnica de Ambato, Centro de Idiomas.

Ambato, Ecuador

ORCID:

http://orcid.org/0000-0002-6618-1559

\section{Cynthia Soledad Hidalgo-} Camacho

cs.hidalgo@uta.edu.ec

Universidad Técnica de Ambato, Centro de Idiomas.

Ambato, Ecuador

ORCID:

http://orcid.org/0000-0002-2848-3687

Verónica Paulina CarreraMartínez

veropauc@hotmail.com

UE Joaquín Lalama. Ambato,

Ecuador

ORCID:

https://orcid.org/0000-0002-0121-8701

\section{GRAPHIC ORGANIZERS FOR THE ENHANCEMENT OF EFL READING COMPREHENSION}

\section{ORGANIZADORES GRÁFICOS PARA EL FORTALECIMIENTODE LA COMPRENSIONLECTORA EN INGLES COMO LENGUA EXTRANJERA}

DOI:

https://doi.org/10.37135/chk.002.12.07

Artículo de Investigación
Recibido:

$(14 / 10 / 2019)$

Aceptado:

$(12 / 03 / 2020)$

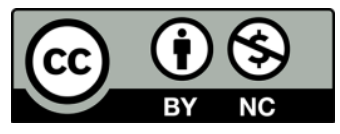


Número 12 / DICIEMBRE, 2020 (95-117)

\section{GRAPHIC ORGANIZERS FOR THE ENHANCEMENT OF EFL READING COMPREHENSION}

ORGANIZADORES
GRAFICOS PARA EL
FORTALECIMIENTO
DE LA COMPRENSIQN
LECTORA ENINGLES
COMO LENGUA
EXTRANJERA

\begin{abstract}
It is widely known that effective readers are those who have appropriately developed reading skills. If those skills are not developed, the readers will not achieve the levels of perception needed to solve problems or pass academic tests, neither in their mother tongue nor in a foreign language. For this reason, it is imperative to find the right strategies to enhance reading comprehension in English as Foreign Language (EFL) learners. One of those strategies is the use of graphic organizers, and this study aimed to measure the extent to which it influences the development of reading comprehension of Unidad Educativa Joaquin Lalama students, in Ambato-Ecuador. 40 students in the control group and 35 students in the experimental group constituted the sample. The data was collected through the observation technique and the comparison of results from a reading comprehension pre-test and post-test. Finally, this study found the use of graphic organizers to be effective for developing reading comprehension in the subjects observed.
\end{abstract}

Palabras clave: Reading comprehension, english as foreign language, graphic organizers, reading skills.

\section{Resumen}

Es ampliamente conocido que los lectores efectivos son aquellos que han desarrollado apropiadamente las destrezas necesarias para leer. Si esas destrezas no son desarrolladas, los lectores no alcanzarán los niveles de interpretación necesarios del texto para resolver problemas o para simplemente pasar pruebas académicas, ya sea en su lengua materna o en una lengua extranjera. Por esta razón, es imperativo encontrar estrategias correctas para fortalecer la comprensión lectora en estudiantes de Inglés como lengua extranjera. Una de esas estrategias es el uso de organizadores gráficos, por lo que el presente estudio se enfocó en medir hasta qué punto ello influye en el desarrollo de la comprensión lectora en los estudiantes de la Unidad Educativa Joaquín Lalama, en Ambato, Ecuador. La muestra estuvo formada por 40 estudiantes en el grupo de control y 35 estudiantes en el grupo experimental. La información fue recogida a través de la técnica de observación y la comparación de resultados de una pre-prueba y una post-prueba de comprensión lectora. Finalmente, se pudo descubrir que el uso de organizadores gráficos para el desarrollo de la comprensión lectora en los sujetos observados fue efectivo.

Keywords: Comprensión lectora, inglés como lengua extranjera, organizadores gráficos, destrezas de lectura 


\section{INTRODUCTION}

Undoubtedly, English has become an important language that is currently used for communication in the scientific, technological, political, and the economic field. This language has also been globally spread through entertainment. In fact, as estimated years ago, the number of learners of English as a foreign language would continue to grow, at least in China and India (Graddol 2006:168).

Similarly, in Ecuador, English is probably considered the most important foreign language, a lingua franca, including by indigenous communities such as Yungantza, whose members have shown an interest in learning this foreign language due to the expectations for better academic and employment opportunities (Sánchez \& Zajkowski 2016:2).

As it can be understood from this particular example, being proficient in English has been associated with better job opportunities and overall knowledge, particularly because the most recent scientific and academic information is found in English. Consequently, for several years now, the Ecuadorian Education System has given EFL teaching a significant importance, making the English Subject a meaningful part of the curriculum in primary school and high schools.

Learning a new language definitely involves many skills or capabilities to understand and express effectively. The four main language skills are Listening, Speaking, Reading and Writing. In our country, a place where there is no immersion and English is a foreign language rather than a second one, teachers need to be inventive and try to use authentic elements, given that their input might be the only one received by students in their learning process (Bekes 2016).

Spratt, Pulverness and Williams, have emphasized the characteristics of reading as a receptive skill, which means that this activity involves reacting to a text rather than creating one (Spratt, Pulverness \&
Williams 2005:21-26). Reading comprehension is a complex cognitive process of decoding symbols to obtain meaning. It comprises the comprehension of a text at a word level, and at a sentence and paragraph level, as well. In order to help learners, teachers must have a clear understanding of the complexity of reading and try to find ways to ease such a complex process.

Years ago, UNESCO pointed out that third grade students from some Latin American countries, including Ecuador, are not able to recognize important information in simple texts in Spanish (López 2009:1-3). Again, the information is confirmed in 2016 when third graders from schools in Ecuador, Guatemala, Honduras, Dominican Republic, among others, still showed low performance in reading, not being able to identify key information unless explicitly stated and highlighted in a text.

Similar results were found especially in public high schools when the standard of the English language was evaluated in Ecuador. Common issues such as class size, the need to train teachers more and even an actual shortage of teachers appeared in the teaching-learning process that might affect it negatively. The truth is that, despite the efforts made in the EFL classroom, student's performance seems to be rather low.

For instance, high schoolers who attend Unidad Educativa Joaquin Lalama have showed to feel demotivated when reading in either Spanish or English due to the lack of the strategies needed to understand texts effectively. Thus, how can we help students become readers that are more effective? Are we using the right strategies when we teach reading? Worldwide, teachers are probably wondering the same and exploring different options; for example, Wong (2019) implemented a 14-week syllabus that incorporated practice on recognizing discourse structures and using graphic organizers in an EFL class.

Although this researcher concludes that further study about the benefits of graphic organizers in foreign language teaching context is needed, others affirm that using graphic organizers can improve students' reading skills because they develop the necessary cognitive abilities for understanding 
learning materials containing interesting graphics (Kurniaman, Oktari \& Pahrurazi 2019).

Based on a theoretical perspective, this study proposed graphic organizers as tools to be used for the enhancement of reading comprehension in junior year students at Unidad Educativa Joaquin Lalama in the Academic Year 2018-2019.

\section{METHODOLOGY}

One of the investigators of this study is currently working at Unidad Educativa Joaquin Lalama and obtained the permission from its authorities to carry out this research, trying to find a way to help students improve their reading comprehension in English. Consequently, the groups assigned to the researcher in the academic period 2018-2019, before and after intervention, were observed.

Barreiro and Albandoz (2001) have defined population as the total amount of individuals studied in a problem. Since the total number of students in this research was less than 100, the population and sample will be considered as one, making up a control group of 40 students, and an experimental group of 35 .

This research work was based on a quasiexperimental design and it is a nonequivalent group design, which means that a pretest and a post-test will be needed to compare two groups: one treated and the comparison one. In this type of research, the independent variable is manipulated and participants are not randomly assigned to conditions.

Such practice is normally found in naturalistic environments and the evaluation of social work practice (Thyer 2012:77-106). Some of the characteristics of this work result from the combination of qualitative and quantitative methods that study the character of prospective educational reality (Marzano, Vegliate \& De Angelis 2015:406).

Graphic organizers are used to help the readers comprehend content of a text and their use has been studied scientifically for over three decades (Wills \& Ellis 2008:1). In fact, they are defined as a "visual representation of information in a text" that can be used with learners as an aid to develop reading comprehension (Jiang \& Grabe 2007:34).

A pre and a post reading comprehension test were designed to compare the results before and after

Table 1: Characteristics of the instruments used

\begin{tabular}{|l|l|}
\hline Reading & Graphic Organizer \\
\hline TRAVEL & K-W-L CHART \\
\hline LIMITED RESOURCES & B-D-A CONNECTION CHART \\
\hline WAVES AND CURENTS A TRIBAL & $\begin{array}{l}\text { BUILDING AND REVISING } \\
\text { SCHEMA CHART (B-R-S } \\
\text { WHAT IS A GART) } \\
\text { GOVERNMENT }\end{array}$ \\
\hline HIDE AND SEEK & KONCEPT WEB \\
\hline GALILEO AND HIS TELESCOPE & \\
\hline
\end{tabular}

Source: Pre-test and post-test questions proposed by the researchers 
an intervention that lasted 6 weeks. Variedaspects were observed in the instruments created for this research, as it can be seen in table N. 1 .

During the intervention period, teachers guided students through the use and familiarization with different graphic organizers that were considered appropriate for each reading text. The reading material was selected taking into account the age and interest of the group in order to engage students. Every time new graphic organizers were presented to the experimental group, the teacher highlighted their purpose and how to use them; whereas the control group continued working with reading activities, as they usually had been doing.

Graphic Organizers for reading fall into the category of Graphic Strategies. Although there is a large amount of them, the most common ones are concept maps, mind maps, webs and Venn diagrams. Based on previous studies and their practicality, the following graphic organizers were chosen for the study: K-W-L chart (know, want to know, learned); K-W-L-S chart (know, want, learned, still); BRS chart (building and revising know schema chart; Sixty second Skim and Scan; Cluster web; Concept web; Alphabet brainstorming; Questioning cluster and B-D-A connection chart (before, during and after reading). Some can be seen in figure 1:

A mixed method, an assessment questionnaire and a short interview were used as instruments that, along with rubrics, measured students' knowledge about the texts. Finally, the data obtained was collected and analyzed by using statistical methods with the following variables and hypothesis:

Independent variable: Graphic Organizers.

Dependent variable: Reading Comprehension.

Null Hypothesis (H0): Using graphic organizers do not affect students' reading comprehension development.

Alternative Hypothesis (H1): Using graphic organizers do affect students' reading comprehension development.

Source: questionnaire created by the researchers

\begin{tabular}{|l|l|}
\hline $\begin{array}{l}\text { GRAPHIC } \\
\text { ORGANIZER }\end{array}$ \\
\hline K-W-L Chart
\end{tabular}

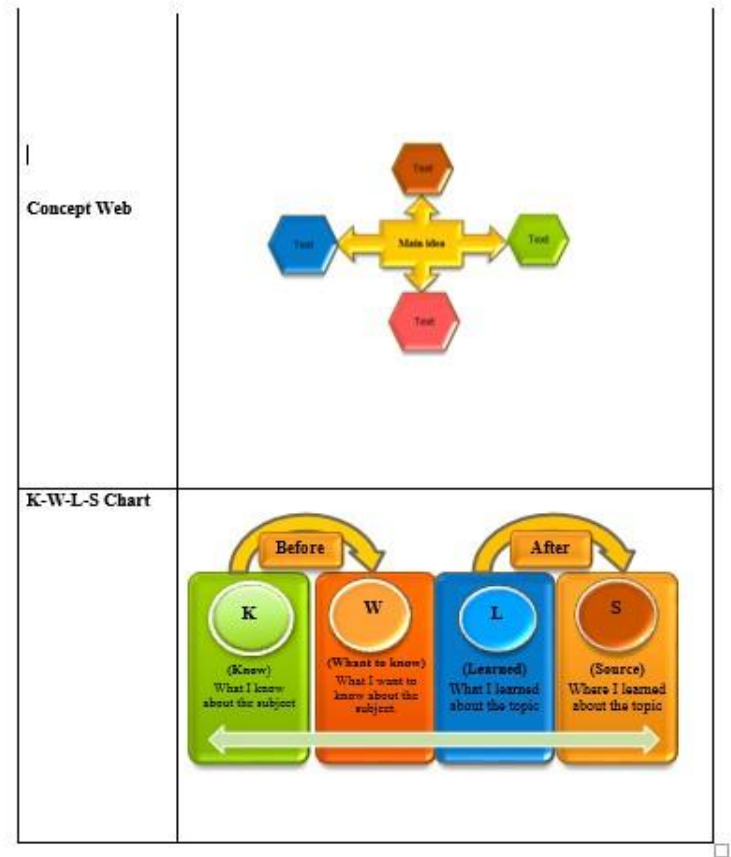

Figure 1: Graphic organizers used in this research work, proposed by the researchers 


\section{READING IN OUR CONTEXT}

\section{RESULTS AND DISCUSSION}

\begin{abstract}
After identifying, the weakness students have when reading texts in English and having reviewed information about some strategies and their effectiveness, this research aimed to measure the benefits of using graphic organizers to improve EFL reading comprehension. In order to do this, graphic organizers were used in the three different stages: pre, during and post reading stages.
\end{abstract}

\section{EFL IN ECUADOR}

\begin{abstract}
Both English learners and non-learners feel that English is a tool for increasing employability, and 59 per cent of nonlearners would study the language to improve their career prospects; English learners also emphasize the importance of English for communicating with others. (British Council 2015: 8)
\end{abstract}

Acknowledging the importance of obtaining the English language proficiency, since 2012, special attention has been given to this foreign language in the educational field. As a result, English teachers in all the country are encouraged to use innovative and appropriate ways to teach this language in order to obtain positive results that would place the country and its people on a more international stage.

It has to be kept in mind that Ecuadorian teachers face heterogeneous classes where they have to teach students with different cultural backgrounds and different learning styles, which makes planning a lesson that would reach everyone, rather challenging. Teachers need to offer students different opportunities to engage in meaningful tasks where higher order thinking skills and problem solving abilities can be developed in real contexts, for this reason innovating our way to teach reading showed to have a great impact that could lead to obtaining the desired results in EFL.
As mentioned before, Latin American countries generally have low reading levels. This has caught the attention of the Ecuadorian government that has tried to come up with ideas to foster reading and improve the levels of comprehension of texts in our country. One of those ideas is Fiesta de la Lectura, which is a national plan that proposes a 30-minute period during class in specific days, which is dedicated to promote reading in schools addressing issues and combining reading with recreational activities (Ministerio de Educación 2018).

In the same tenor, other Latin American countries have also adopted this type of strategies to promote reading, such as Playing with Magic Words, in Bolivia, Read Together - Learn Together in Peru, Extracurricular Clubs in Mexico, and The magic of Reading in Guatemala, showing good results (Save the Children 2015).

However, low reading comprehension may seem to be linked to the lack of reading strategies, and consequently, there is little acquisition of vocabulary. If this is what our students face in their first language (L1), it is only reasonable to think that the reading process is more complex for them in English. As expected, low percentages were found in the pre-test used, as it can be seen in table N.2:

Table N.2 shows that both groups seem to lack proper reading skills such as using their own words to interpret content, adding new ideas or predicting and giving opinions or establishing connections in the information presented. This was observed through the analysis of the results existing in some of the questions specifically formulated to measure those skills (control group 3,92 points and 4,22 points the experimental one). It can also be seen that there is a noticeable improvement in the experimental group that obtained 7,02 out of 10 in the post-test, which means the proposal to use graphic organizers to enhance reading was effective, agreeing that graphic organizers are useful when trying to understand information (Graves \& Graves 2003). 
Table 2: Reading Skills results in the pre-test and the post-test

\begin{tabular}{|l|c|}
\hline \multicolumn{1}{|c|}{ Tests- Groups } & Results \\
\hline Pre-test Control & 3,92 \\
\hline Pre-test Experimental & 4,22 \\
\hline Post-test Control & 4,6 \\
\hline Post-test Experimental & 7,02 \\
\hline
\end{tabular}

Source: Pre-test and post-test results from the experimental and control groups obtained by the researchers

\section{GRAPHIC ORGANIZERS AND LEARNING}

Locally, Tirado (2013) implemented a study about the use of active techniques to enhance reading comprehension in fifth year English learners in a primary school. In this study, it was found that the application of traditional techniques discourages students when reading; however, children also showed interest in learning to read better. That study, among others, has inspired teachers to find ways to provide EFL learners with proper strategies to read better.

Since graphic organizers are tools that facilitate the organization or information or the establishment of relationships between elements of a text such as facts, examples, definitions, sequences, among others, their use allows the readers break down the content of the reading while they think about the information they are getting from the text. Using them, definitely improved the levels of reading comprehension in the experimental group, as it can be observed in table N. 3 .

From the observation and the comparison of the low results obtained in the pre-test: 4,05 for the control group and 4,14 out of 10 points for the experimental group, it can be said that students are demotivated when reading because they lack tools that allow them to comprehend a text. This information was used to propose the use of graphic organizers to enhance their reading comprehension.

After the intervention, the experimental group showed a significant improvement in their scores (7.06). This clearly shows that using graphic organizers helped students in their reading comprehension tasks, turning them into more effective readers. Reading comprehension needs to be developed through the analysis and synthesis of information, and visual help provided by graphic organizers is definitely important in that process too. (Pearson \& Fielding, 1991).

From the educational point of view, there are some approaches and cognitive processes that support the use of graphic organizers, especially those related to Bloom's taxonomy. When these tools are to be used, it must be remembered how they are linked to the different stages or levels of thinking.

Using a simple flow chart can be used to remember or understand information; however, for application and analysis students should be required to use different graphic organizers to compare and contrast information, or organizers to evaluate cause and effect, positive and negative sides of something if the highest level of thinking is the aim.

Graphic organizers are also useful when trying to reach students' different learning styles. They are perfect for visual learners because they train readers to understand symbols and key words, and on top of that, they are a varied and interesting way of learning. Research has shown that graphic 
Table 3: Reading Comprehension Results in the pre-test and the post-test

\begin{tabular}{|l|c|}
\hline \multicolumn{1}{|c|}{ Tests- Groups } & Results \\
\hline Pre-test Control & 4,1 \\
\hline Pre-test Experimental & 4,11 \\
\hline Post-test Control & 4,33 \\
\hline Post-test Experimental & 6,46 \\
\hline
\end{tabular}

Source: Pre-test and post-test results from the experimental and control groups obtained by the researchers

organizers are useful not only as preparation activities, but also as follow up learning tasks (Dishner, Bean, \& Readence, 1981).

With graphic organizers, readers can separate key information from the rest of the content; use strategic learning and improve other skills related to writing, reading, communication, analysis and creativity, fostering better overall performance, as can be perceived from the results obtained in the assessment of learning skills presented in table $\mathrm{N}$. 4.

During the evaluation of learning skills, students from the control group obtained 4,05 and the experimental group 4,17 in the pre-test, which suggested that students' learning skills such as decoding and understanding new vocabulary are rather poor. After implementing the use of graphic organizers to enhance reading comprehension, there was no significant change in the results obtained by the control group. Actually, results slightly decreased.

Table 4 also shows that results were better for the experimental group in the post-test: 6,57 out of 10 , which means that graphic organizers also influenced positively the development of learning skills.

How did graphic organizers help the readers? As it was mentioned before, graphic organizers that are

Table 4: Learning Skills Results in the pre-test and the post-test

\begin{tabular}{|l|c|}
\hline \multicolumn{1}{|c|}{ Tests- Groups } & Results \\
\hline Pre-test Control & 4,05 \\
\hline Pre-test Experimental & 4,14 \\
\hline Post-test Control & 4,73 \\
\hline Post-test Experimental & 7,06 \\
\hline
\end{tabular}

Source: Pre-test and post-test results from the experimental and control groups obtained by the researchers 
used in reading belong to the category of Graphic Strategies. Shabiralyani, Hasan, Hamad and Iqbal (2015) relate visual aids and education, stating that visual aids are important because they disseminate knowledge and make teaching more effective.

Additionally, Pearson and Fielding (1991) indicate that 75 percent of all information is processed from visual formats by the brain: images, diagrams, flowcharts, video, graphs, cartoons, coloring books movies, posters, games and flash cards. Undoubtedly, all the different ways of graphic strategies support teacher and students' interaction.

\section{HYPOTHESIS VERIFICATION}

The present research work collected and analyzed the information from two groups: the experimental and the control one. Graphic organizers were used as a strategy to help students enhance reading comprehension, formulating the following hypothesis:

- Using graphic organizers do not affect student`s reading comprehension development $(\mathrm{Ho})$

- Using graphic organizers do affect student`s reading comprehension development $(\mathrm{Hl})$

Since the quasi-experimental approach was selected, there was two different measurements, one with a pre-test (before intervention) and one with a post-test (after the intervention).

The selected level of significance for this social science research was $\alpha=0.05$ and a risk of $5 \%$ is assumed, making the confidence level equals to $95 \%$.

More than 30 subjects made up the sample; therefore, Kolmogorov-Smirnov test is recommended for this kind of study.

The estimation of P Value was also made, as shown below in table 5 .

As it can be evidenced in the table above in the Wilconxon test for pretest and posttest on each criteria, the following results can be observed beginning with the experimental group: Reading Comprehension $\mathrm{Z}=-5,131$ (a) with a $\mathrm{p}=0,000$.

The control group results as following: Reading Comprehension $\mathrm{Z}=-4,292$ (a) with a $\mathrm{p}=0,000$. Keeping in mind that $Z$ values are negative and $p$ values are less than 0,05 , it can be deduced that the results obtained in the pre-test and post-test in the experimental and control groups present significant differences. Therefore, it can be stated that the use of graphic organizers to enhance students reading comprehension is effective. Although both groups present considerable differences, we cannot affirm that the improvement presented in reading comprehension is due only to the use of this strategy.

Table 5: Estimation of $P$ value

\begin{tabular}{|l|c|}
\hline \multicolumn{1}{|c|}{ Tests- Groups } & Results \\
\hline Pre-test Control & 4,05 \\
\hline Pre-test Experimental & 4,17 \\
\hline Post-test Control & 4,03 \\
\hline Post-test Experimental & 6,57 \\
\hline
\end{tabular}

Source: SPSS 23.0 software, by the researchers 


\section{CONCLUSIONS}

This research proposed to measure the extent to which the use of graphic organizers influences the development of reading comprehension of junior year students at Unidad Educativa Joaquin Lalama in Ambato-Ecuador.

After analyzing the low level of reading proficiency that students had at the beginning of this research, as well as the improvement of reading comprehension obtained by the experimental group in the post-intervention test, it can be said that the use of graphic organizers strengthened reading comprehension in the students in this research work.

Following the implementation of reading activities with graphic organizers during 6 weeks, most of the students in the experimental group demonstrated acceptance and comprehension of how these tools are used. They also showed significant improvement in the development of their receptive skills, such as listening and concentration, their reading comprehension and their learning skills, for example decoding and understanding vocabulary and relating content to previous knowledge.

Although both groups presented important differences in the results obtained after intervention, it cannot be statistically guaranteed that the improvement in the post-test from the experimental group is solely due to this strategy, which is why further research in the topic is recommended, if possible, for a longer period to confirm the usefulness of the proposal.

In fact, other aspects need to be taken into account, such as the selection of texts. It must be remembered that readers who struggle with the comprehension of a text, lose interest and motivation (Hansen, 2016). For this reason, students' interests and preferences need to be discovered when teaching reading.

It is also advisable, although there is normally time limitation, to assess the level of reading comprehension students have in their mother tongue so that teachers could provide them with strategies that can be transferable into their foreign language learning. Supporting this, (Cheryl 1994) stated that there is evidence of reading skills transfer from one language into another.

Since the findings in this work suggested that there is very little or maybe no use of graphic organizers in EFL classrooms to develop reading skills and comprehension, it is suggested to inform teachers about the benefits that can be obtained from this proposal.

The effectiveness of graphic organizers for improving reading comprehension in the EFL classrooms has been proven. They provide students with visual tools such as images, which expand the development of linguistic data or logogens in such a way, that the information is dually coded: visually and linguistically. This helps students process and remember content.

Using graphic organizers for reading comprehension enhancement is a good alternative to the traditional methods that usually involve the activities suggested in textbooks. Therefore, the researchers made a proposal after the study: a selection of graphic organizers and activities that can help other EFL teachers and their students organize information found in texts during reading lessons.

Motivating reading with innovative ways of teaching this skill, such as the use of graphic organizers, is definitely encouraged because being an effective reader does not only help in daily activities, texts comprehension in L1 and texts comprehension in English. It also develops other important cognitive skills and increases students' motivation as a result of improved vocabulary knowledge and better texts comprehension.

\section{DECLARATION OF CONFLICTS OF INTEREST:}

The authors declare no conflict of interest. 


\section{BIBLIOGRAPHICAL REFERENCES}

Barreiro, P. \& Albandoz, J. (2001). Population and sample. Sampling techniques. Management Mathematics for European Schools. Retrieved from https://optimierung. mathematik.uni-kl.de/mamaeusch/ veroeffentlichungen/ver_texte/sampling_ en.pdf

Bekes, E. (2016). Teaching English in Ecuador. EFL Magazine. Retrieved from https:// www.eflmagazine.com/teaching-englishecuador/

British Council. International Educational Services. (2015). English in Ecuador: an examination of policy, perceptions and influencing factors. Retrieved from https://www.teachingenglish.org.uk/sites/ teacheng/files/English\%20in\%20Ecuador. pdf

Cheryl, R. (1994). Transferring literary skills from L1 to L2: from theory to practice. The Journal of Educational Issues of Language Minority Students, 13, 209-221 Retrieved from: https://ncela.ed.gov/files/ rcd/BE019750/Transferring_Literacy.pdf

Dishner, E., Bean, T., and Readence, J. (1981). Reading in the content areas: Improving classroom instructions. Dubuque, USA: Kendall/Hunt.

Graddol, D. (2006). English next: why global English may mean the end of English as a foreign language. Retrieved from https://www.teachingenglish.org.uk/sites/ teacheng/files/pub_english_next.pdf

Graves, M. and Graves, B. (2003). Scaffolding reading experiences: designs for students' success. Second Edition. Norwood, Massachusetts: Christopher-Gordon.

Hansen, E. (2016). Reading Comprehension. Retrieved from: https://brage. bibs y s.no/x m lui/bitstream/ handle/11250/2396307/16-00400-21\%20

Masteravhandling\%20-\%20Reading\%20 com pre he nsi on $\% 2$ C $\% 20$ E 1 in $\% 20$ Jorde\%20Hansen.docx\%20267995_1_1. pdf? sequence $=1$

Jiang, X. \& Grabe, W. (2007). Graphic organizers in reading instruction: Research findings and issues. Reading in a Foreign Language, 19(1), 34-35.

Kurniaman, O., Oktari, C. \& Pahrurazi, P.(2019). The Implementation of Teaching Materials Reading Graphic Organizers in Elementary Schools. Lensa: Kajian Kebahasaan, Kesusastraan, dan Budaya, 9(2), 105-119.

López, L. E. (2009). Llegando a los no alcanzados: interculturalidad indígena educación bilingüe en América Latina. París: UNESCO. Retrieved from https://unesdoc. unesco.org/ark:/48223/pf0000186620

Marzano, A., Vegliante, R. \& De Angelis, M. (2015). Quali-quantitative approach in educational research. Conference: 9th International Technology, Education and development Conference. Madrid, Spain. Retrieved from https://www.researchgate. net/publication/280521706_QUALIQUANTITATIVE_APPROACH_IN_ EDUCATIONAL_RESEARCH

Ministerio de Educación. (2018). Lineamientos Generales fiesta de la lectura. Retrieved fromhttps://drive.google.com/file/ B048WkRgr8JQaFpUeWVvSWIDNFk/ view

Pearson, P. and Fielding. (1991). Comprehension instruction. Handbook of Reading Research, 2, 815-860. Retrieved from: https:// scholar.google.com/scholar?hl=es\&as $\mathrm{sdt}=0 \% 2 \mathrm{C} 5 \& \mathrm{q}=$ Pearson $\% 2 \mathrm{C}+\mathrm{P} .+$ and +Fielding.+\%281991\%29.+Com prehens ion + instruction. $+\mathrm{H}$ and b o o k + of $+\mathrm{R}$ e a d i n g $+\mathrm{R}$ e s each $\% 2 \mathrm{C}+2 \% 2 \mathrm{C}+815-860 . \& \mathrm{bt}$ $\mathrm{nG}=\# \mathrm{~d}=\mathrm{gs} \_\mathrm{t} \& \mathrm{u}=\% 2 \mathrm{Fsch} 3 \mathrm{Dinfo} \% 3 \mathrm{~A}-$ GaGL1U9IJecJ\%3Ascholar.google. tput\%3Dcite\%26scirp\%3D0\%26hl\%3Des 
Sánchez, P. J. \& Zajkowski, M. R. (2016). English language instruction, student engagement, and sustainable practices in rural Ecuador. Journal of Vincentian Social Action, 1(1), 5.

Save the Children. (2015). Promoting literacy in Latin America. Retrieved from https:// docplayer.net/59206288-Save-thechildren-promoting-literacy-in-latinamerica.html

Shabiralyani, G., Hasan, K. S., Hamad, N. and Iqbal, N. (2015). Effects of TeacherConstructed Pre- and Post-Graphic Organizer Instruction on Sixth-Grade Science Students' Comprehension and Recall. Journal of Education and Practice, 6(19), 226-233. Retrieved from: https:// www.tandfonline.com/doi/abs/10.1080/00 220671.1988.10885859

Spratt, M., Pulverness, A. \& Williams, M. (2005). The TKT (Teaching knowledge test). Cambridge, England: Cambridge University Press.

Thyer, B. (2012). Quasi-experimental research designs. Retrieved from https://www. researchgate.net/publication/286122828_ Quasi-Experimental_Research_Designs

Tirado, P. (2013). Utilización de técnicas activas para fortalecer la lectura comprensiva en el idioma inglés de los niños de quinto año de educación general básica del centro educativo ecuatoriano holandés, de la ciudad de Ambato, provincia de Tungurahua. Ecuador (Research work - Bachelor degree). Universidad Técnica de Ambato, Ecuador. Retrieved from http://repositorio.uta.edu.ec/ handle/123456789/4753

Wills, S. \& Ellis, E. (2008). The Theoretical and Empirical Basis for Graphic Organizer Instruction. Retrieved from http://www.calhoun.k12.al.us/files/ makessense\%202010/DoNotOpenFolder/ Implmnt/DONTOPEN/MSStrats/Stuf/ TheoreticBasis.pdf

Wong, S. (2019). The Effectiveness of Graphic Organizers on the Reading Comprehension of EFL Students: A Proposed Syllabus. Studies in applied linguistics, 73. 